\title{
EKSTRAKSI ASAM LEMAK BEBAS DARI MINYAK NABATI DENGAN METANOL KAJIAN PERPINDAHAN MASSA
}

\author{
Wahyuningsih, Moh Endy Yulianto \\ Program Studi Diploma III Teknik Kimia \\ Fakultas Teknik Universitas Diponegoro
}

\begin{abstract}
Wahyuningsih, Moh Endy Yulianto, in this paper explain that extraction of free fatty acids from vegetable oils with methanol performed in batch stirred tank, in a variety of conditions. Variables experiments in liquid-liquid extraction including temperature, solvent ratio and rotational speed stirrer. This study aims to develop a correlation coefficient of mass transfer in extraction of free fatty acids from vegetable oils methanol. Rresearch was conducted in two phases. Was the first stage liquid-liquid extraction experiments in laboratory. Second step is the development of an empirical correlation for the mass transfer coefficients in the form of numbers not berdemensi results showed that the greater the temperature, turn the mixer speed and solvent-feed ratio of the mass transfer koffisien gained greater. Mass transfer coefficient expressed in Sherwood number and correlated against the Reynolds number, Schmitd, $(d P / d T)$ and $(L / S)$, the results obtained:$$
S h=4,669 \times 10^{-5} \operatorname{Re}^{0,462} \mathrm{Sc}^{0,5}(\mathrm{dP} / \mathrm{dT})^{0,308}(\mathrm{~L} / \mathrm{S})^{0,187}
$$

If used to calculate the mass transfer coefficients, have an average error of $8.79 \%$ for the regression line. This equation was developed in the Re number range 3169 to 11 750; numbers Sc 6321 to 9896, (dp / dT) from 0.0007 to 0.0013 and $(L / S)$ of 0.333 to 1.
\end{abstract}

Keywords: nabati oil extraction

\section{PENDAHULUAN}

Kelapa sawit merupakan salah satu sumber minyak nabati yang sangat potensial khususnya sebagai bahan oleopangan dan oleo kimia. Sebagai oleopangan minyak kelapa sawit digunakan untuk minyak goreng,margarin, shortening agent dan pengganti lemak coklat ( cocoa butter) ,sedangkan sebagai oleokimia dapat berupa asam lemak, metyl ester, lemak amina, gliserin, lemak alkohol, pelumas, platisizer,,kosmetik dan alternatif bahan bakar (Othmer,1992)

Berkaitan dengan ekstraksi asam lemak bebas dalam minyak sawit,dua kajian yang diperlukan,antara lain:

- Kesetimbangan cair-cair sistem minyak nabatiasam lemak bebas-metanol

- Perpindahan massa dalam ekstraksi asam lemak bebas

Kajian pertama telah dilakukan oleh trisaksi(1996) dan Silviana(2001). Kedua peneliti telah menelaah data kesetimbangan sistem minyak nabati-asam lemak bebas dan metanol, baik menyangkut pengukuran data maupun perhitungan menggunakan model-modek thermodinamik. Masalah yang tertinggal saat ini adalah ketiadaan data koeffisien perpindahan massa yang sangat penting peranannnya dalam penentuan effisiensi jumlah tahap ekstraksinya.

Kajian korelasi koeffisien perpindahan massa dalam penelitian ini dibatasi :
- Ektraksi di dalam tangki berpengaduk yang beroperasi secara batch

- Sebagai minyaqk nabati digunakan minyak sawit, mengingaqt minyak sawit diproduksi dalam jumlah banyak di Indonesia

- Asam oleat digunakan asam lemak bebas

- data koeffisien perpindahan massa yang diperoleh akan diringkas dalam korelasi empirik

\section{Tujuan Penelitian}

Berdasarkan latar belakang dan perumusan masalah yang telah dibahas diatas maka penelitian ini bertujuan untuk mengem bangkan korelasi koeffisien perpindahan massa pada ekstraksi asam lemak bebas dari minyak nabati dengan metanol

\section{Manfaat Penelitian}

Penelitian ini beroreantasi untuk melengkapi penelitian dasar tentang studi ekstraksi dalam menyingkirkan asam lemak bebas dari minyak nabati dengan telaah perpindahan massa.Informasi data koeffisien perpindahan massa produksi metyl ester dengan proses ekstraksi sampai saat ini belum ada. Hasil dari penelitian ini diharapkan dapat dikembangkan dan di scale up oleh industri minyak sawit mentah dan industri meyl ester sebagai upaya pemenuhan kebutuhan metyl ester dalam negeri,mengingat produksi metyl ester yang sudah ada di Indonesia masih menggunakan metode konvensional 


\section{METODE PENELITIAN}

Minyak sawit mewakili minyak nabati ,yang digunakan dalam penelitian ini diperoleh dari toko (Semarang).Asam Oleat,metanol teknis,alkohol dan bahan kimia untuk keperluan analisa (air,KOH dan indikator pp) diperoleh dari PT Brataco(Semarang).

Variabel-variabel percobaan dalam dalam ekstraksi cair-cair adalah temperatur, ratio pelarutumpan, dan kecepatan putar pengaduk. Adapun temperatur percobaan ditetapkan pada : 40, 45 dan $50^{\circ} \mathrm{C}$, karena daya larut asam lemak bebas dalam metanol pada rentang temperatur ini cukup besar dan untuk mencegah penguapan penguapan metanol secara berarti. Konsentrasi asam asam lemak bebas ditetapkan 8\% berat, karena merupakan rentang fluktuasi konsentrasi asam lemak bebas dalam minyak sawit . Ratio pelarut-umpan ditetapkan $3: 1$; 2: 1 dan 1:1 (W/W) .Sedangkan kecepatan putar pengaduk pada 700,850 dan $1000 \mathrm{rpm}$. Karena rentang kecepatan ini merupakan zona turbulen.

\section{PROSEDUR PERCOBAAN}

Umpan ( Minyak + asam lemak bebas) dan pelarut metanol yang telah dikondisikan pada temperatur tertentu dengan perbandingan tertentu pula dimasukkan ke dalam tangki. Sebelum umpan dan pelarut dimasukkan kedalam tangki, tangki dikondisikan pada temperatut yang diinginkan.Perhitungan waktu ekstraksi $(\mathrm{t}=0)$ dimulai ketika pengaduk dengan putaran tertentu dijalankan . Selama ekstraksi berlangsung,sejumlah sampel diambil setiap saat 10 menit. Sampel terdiri dari fasa minyak dan pelarut dipisahkan dalam corongpemisah untuk memperoleh rafinat atau ekstrak. Kadar asam lemak dalam rafinat dianalisa dengan menentukan bilangan asam dalam rafinat.Kadar asam lemak dalam fasa pelarut ditentukan dari neraca massa.

Koeffisien perpidahan massa overall asam lemak bebas ditentuka dengan persamaan :

$\mathrm{K}=\mathrm{ri} / \mathrm{a} . \mathrm{V}(\mathrm{Xi}-\mathrm{Yi})$

Luas muka antar fasa spesifik dihitung dari diameter drop rata-rata ( Sauter mean diameter) sebagai berikut $\mathrm{A}=\mathrm{a} . \mathrm{V}=6 . \varphi / \mathrm{d} 32$

Dimana d32 (sauter mean diameter) diprediksi secara empirik dengan korelasi yang diusulkan oleh Mlynek dan Resnick's (Skeland et al,1992). Korelasi ini direpresentasikan sebagai berikut:

$$
\mathrm{d} 32 / \mathrm{d} 1=0,058\left(1+5,4 \varphi \mathrm{N} \text { w e } \mathrm{e}^{-0,6}\right.
$$

Koeffisien difusivitas Dv diperkirakan dari persamaan Wilke dan Chang (Teryballl,1984).

$$
\operatorname{Dv}=\left(117,3 \cdot 10^{-16}(\varphi \mathrm{M})^{0,5} \mathrm{~T} / \mu v^{0,6}\right.
$$

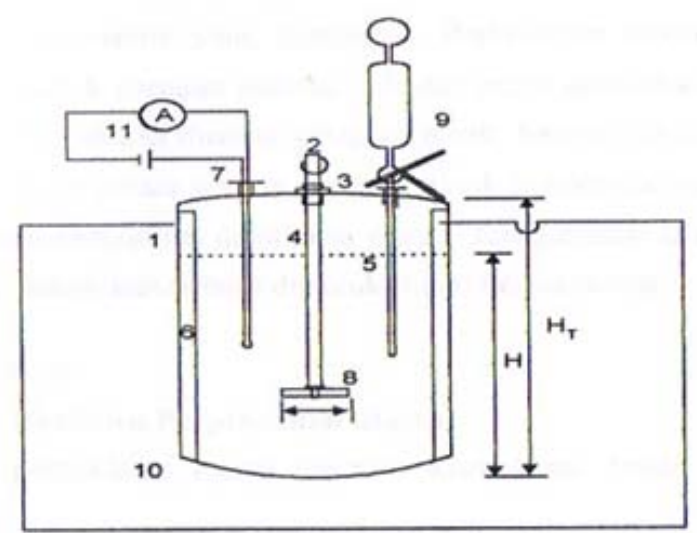

Gambar 1. Rangkaian Percobaan

\section{HASIL DAN PEMBAHASAN}

Gambar kurva ekstraksi typikal (Gambar 2.) menyajikan nilai fraksi berat asam lemak bebas dalam ekstrak maupun rafinat,serta asam lemak bebas yang tersingkir. Kurva ekstraksi terlihat naik secara tajam pada 600 detik ( 10 menit) pertama.setelah melewati waktu 600 detik, kenaikkan fraksi asam lemak bebas dalam ekstrak tidak terlalu tajam. Hal ini menunjukkan ekstraksi cenderung mendekati kesetimbangan setelah 600 detik. Oleh sebab itu,data ekstraksi yang digunakan dalam penetuan koeffisien perpindahan massa dalam tahap selajutnya didasarkan pada 600 detik(10menit)lihat gambar 3.

Koeffisien perpindahan massa umumnya dinyatakan dalam bentuk bilangan Sherwood. Korelasi empirik bilangan Sherwood melibatkan bilangan Reynold dan Schmidt . sebagai langkah pertama,data koeffisien perpindahan dikorelasikan dengan persamaan $\mathrm{Sh}=\mathrm{a} \operatorname{Re}^{\mathrm{b}} \mathrm{Sc}^{\mathrm{c}}$ hasil korelasi ditunjukkan di gambar 4 .

$$
\mathrm{Sh}=6,2 \times 10^{-4} \mathrm{Re}^{0,143} \mathrm{Sc}^{0,267}
$$

Hasil ini ternyata kurang memuaskan,karena memiliki kesalahan rata-rata 12,9\%

Sehubungan dengan hal itu,data-data koeffisien perpindahan massa diregresi kembali dengan menggunakan model yang lain. Model yang digunakan pada dasarnya tetap melibatkan bilangan Re dan Sc,akan tetapi melibatkan bilangan tak berdemensi sepert $\mathrm{dP} / \mathrm{dT}$ dan L/S.Bentuk selengkapnya:

$$
\mathrm{Sh}=\mathrm{a} \operatorname{Re}^{\mathrm{b}} \mathrm{Sc}^{\mathrm{c}}(\mathrm{dp} / \mathrm{dT})^{\mathrm{d}}(\mathrm{L} / \mathrm{S})
$$

Untuk mengurangi jumlah parameter, pangkat bilangan Sc diambil dari teori lapisan film yaitu sebesar 0,33. didapat korelasi: $\mathrm{Sh}=6,2 \times 10^{-4} \mathrm{Re}^{0,194} \mathrm{Sc}^{0,33}(\mathrm{dP} / \mathrm{dT})^{0,140}(\mathrm{~L} / \mathrm{S})^{0,183}$

Jika persamaan 8 dipakai untuk menghitung koeffisien perpindahan massa,maka akan memberikan kesalahan rata-rata 9,67 \% terhadap garis regresi. Persamman 8 dikembangkan pada rentang bil Re dari 3169 sampai 11750, bil Sc 6321 sampai 9897, 
(dP/dT) dari 0,0007 sampai 0,001307 dan (L/S) dari 0,333 sampai 1 .

Hasil korelasi dari model diatas disajikan pada gambar 5. Garis putus-putus menunjukkankesalahan tiap titik kurang lebih 25 \% . Model dengan kesalahan pendekatan teori lapisan film pada dasarnya memberikan hasil prediksi dengan ketepatan hampir sama pada rentang $\mathrm{k}$ lebih $25 \%$.

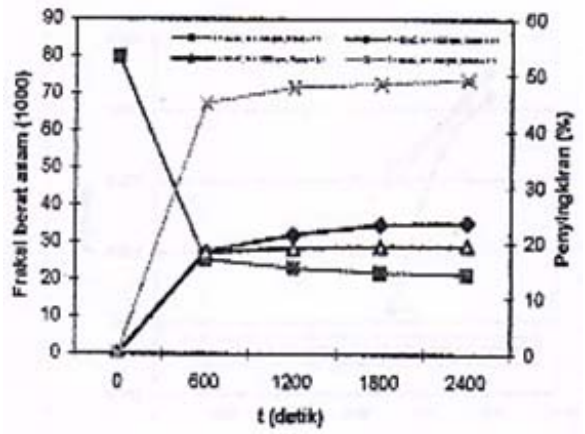

Gambar 2. Kurva Ekstraksi Tipikal

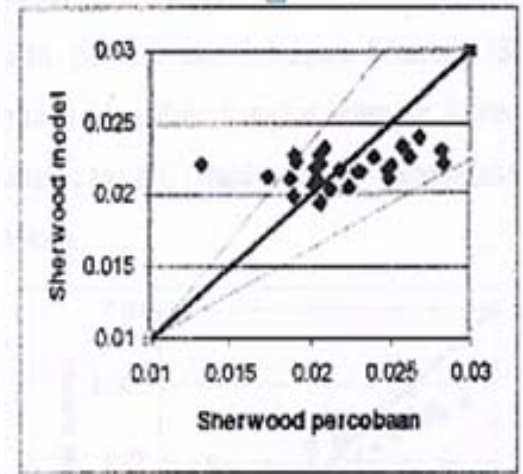

Gambar 3. Hubungan Antara Sherwood model dengan Sherwood percobaan

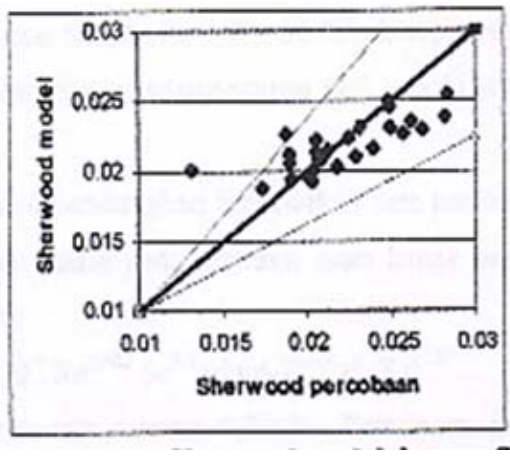

Gambar 4. Hubungan antara Sherwood model dangan Sherwood percobaan dengan pendekatan teori penetrasi

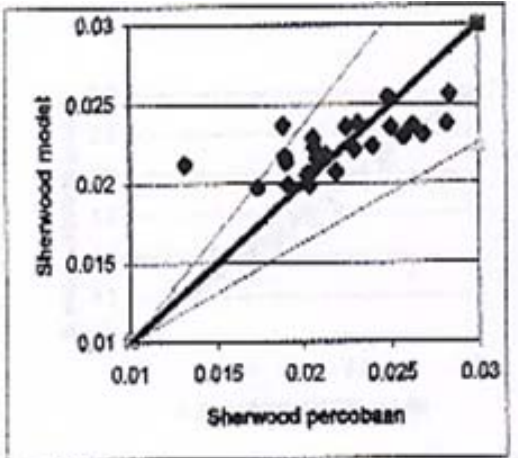

Gambar 5. Hubungan antara Sherwood model dangan Sherwood percobaan dengan pendekatan teori lapisan film

\section{KESIMPULAN}

- Sebuah korelasi telah dikembangkan berdasarkan data percobaan untuk menghitung koeffisien perpindahan massa pada ekstraksi asam lemak bebas dari minyak nabati dengan metanol yaitu $\mathrm{Sh}=0,648 \times 10^{-4} \mathrm{Re}^{0,194} \mathrm{Sc}^{0,333}$ $(\mathrm{dP} / \mathrm{dT})^{0,140}(\mathrm{~L} / \mathrm{S})^{0,183}$ dengan kesalahan ratarata 9,67\% .Persamaan ini dikembangkan pada retang bil Re 3169-11750; Sc 6321-9897; dP/dT dari 0,0007 -0,0011307 dan (L/S) 0,333-1

- Koeffisien perpindahan massa overall mewakili koeffisien perpindahan massa fasa dispersi,karena viskositas fasa dispersi jauh lebih besar dibanding viskositas fasa kontinyu

\section{DAFTAR PUSTAKA}

1. Barker ,J.J.,and Treyball,R.E., 1960, Mass Transfer Coefficients for Solids Suspended in Agitated Liquids, AIChE,J.Vol 6,no 2,p 289298

2. Boon-long,S., Laguerie,C., and Coudere,J.P., 1978, Mass Transfer from Suspended Solids to a Liquid in Agitated Vessls,Chemical Engineering Science, vol 33, p 813-819

3. Geankoplis Science.,1993, Transport Process and Unit Operation, $3{ }^{\text {nd }}$ edition PTR Prentice Hall,Inc

4. Laddha,GS., and Degaleesan,T.E., 1976, Transport Phenomena in Liquid Extraction ,Tata Mc Graw Hill Publishing,Tokyo

5. Lewis,J.B., 1954,The Mechanism of Mass Transfer of Solutes Across Liquid-Liquid interfaces, Chemical Engineering Science, Vol 3,p 248-259

6. Miller,D.N., 1971, Scale Up of Agtated Vessels, Industrial Engineering Chemical Process Design and Development, vol 10, no 3,p 365-375 
7. Rushton,J.H.,Nagala,S.,and Rooney,T.B., 1964, Measurement of Mass Transfer Coefficient in Liquid-liquid Mixing, AIChE,J.,Vol 10 no 3 ,p 298-302

8. Skelland,A.H.P., and Kanel,J.S., 1992, Simulation of Mass Transfer in Batch Agitated Liquid-liquid Dispersion, Industrial and Engineering Chemistry Research ,vol 31, p 908-920

9. Skelland,A.H.V.,and Lee,J.M., 1981, Drop Size and Continous Phase Mass Transfer in Agitated Vessels, AIChE,J.,vol 27 ,no 1, p 99111

10. Skelland,A.H.P.,and Moeti,L.T., $\quad$ 1990, Mechanism of continous -Phase Mass Transfer in Agitated Liquid-liquid Systems, Industrial and Engineering Chemistry research,vol 29,p 2258-2267 